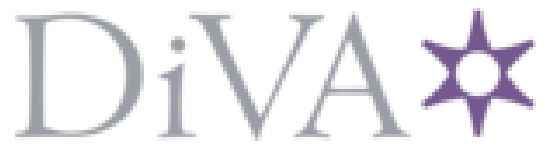

http://www.diva-portal.org

Preprint

This is the submitted version of a paper published in Journal of Interpersonal Violence.

Citation for the original published paper (version of record):

Ceccato, V., Wiebe, D., Eshraghi, B., Vrotsou, K. (2017)

Women's Mobility and the Situational Conditions of Rape: Cases Reported to Hospitals Journal of Interpersonal Violence

https://doi.org/10.1177/o886260517699950

Access to the published version may require subscription.

N.B. When citing this work, cite the original published paper.

Permanent link to this version:

http://urn.kb.se/resolve?urn=urn:nbn:se:kth:diva-233903 


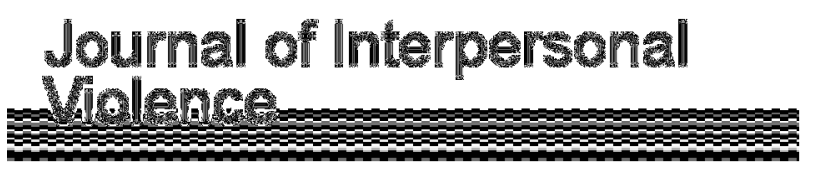

\section{WOMEN'S MOBILITY AND THE SITUATIONAL CONDITIONS OF RAPE: CASES REPORTED TO HOSPITALS}

\begin{tabular}{|r|l|}
\hline Journal: & Journal of Interpersonal Violence \\
\hline Manuscript ID & JIV-16-089.R3 \\
\hline Manuscript Type: & Original Research \\
\hline Keywords: & $\begin{array}{l}\text { Sexual assault < Alcohol and Drugs, Situational factors < Sexual Assault, } \\
\text { Violence against < GLBT }\end{array}$ \\
\hline \multicolumn{2}{|c}{} \\
\hline
\end{tabular}

SCHOLARONE ${ }^{m}$

Manuscripts 


\section{ABSTRACT}

A third of all rapes in Stockholm, the capital of Sweden, take place in public outdoors places. Yet, little is known about the events that precede this type of sexual offence and less about the situational context of rape. This study aims to improve the understanding of the nature of situational conditions that immediately precede events of rape. Using medical records of 147 rape victim during 2012 and 2013, we constructed time and place specific records of the places women's travelled through or spent time, the activities they engaged in, the people they socialized with sequentially over the course of the day when they were raped. The analysis uses visualization tools (VISUAL-TimePAcTS), Geographical Information Systems (GIS), and conditional logistic regression to identify place-, context-, and social interaction-related factors associated with the onset of rape. Results for this sample of cases reported to hospitals show that being outdoors was not necessarily riskier for women when compared with indoor public settings; some outdoor environments were actually protective, such as streets. Being in a risky social context and engaging in a risky activity before the event was associated with an increased risk of rape and the risk escalated over the day. Among those women who never drank alcohol, the results were similar to what was observed in the overall sample, which suggests that risky social interaction and risky activity made independent contributions to the risk of rape. The article finishes with suggestions for rape prevention.

Keywords: sexual violence, visualization techniques, GIS, case-cross over design. 


\section{INTRODUCTION}

Violence in public spaces - from sexual harassment, to rape - is an everyday occurrence for women and girls around the world, in urban and rural areas, and in developed and developing countries (UN Women, 2014). This violence happens on streets, on public transport and in parks, in and around schools and workplaces or in familiar places, such as the victims' neighborhoods. This reality impacts women's freedom of movement and their health and well-being (UN Women, 2014).

The role of environment in rape varies over time and space. Ceccato et al. (2016) showed that the risk of rape increases with opportunities and good accessibility, especially those areas with high population turnover that contain subway stations. At micro level, rapes happen in places with poor visibility that offers an easy escape for the offender, and disproportionately happened on weekends, on holidays and during the warmer months of the year (Ceccato, 2014).

As a next step to more specifically identify location and context-specific factors that are associated with the occurrence of rape, this study of 147 rape cases in Stockholm, Sweden which were reported to hospitals involve an innovative investigation of the nature and location of women's mobility sequentially over the course of the day leading up to the time of the event. By focusing on the visualization and assessment of the situational conditions of these violent events, the objective of this study is to identify particular situational conditions of rape that can be informative in its prevention. Given that rape is never justified, we focus not on woman's actions (over which women are free to have total autonomy and carry out in the absence of the threat of rape), but on locations and temporal contexts that might be targeted to create opportunities for prevention.

\section{THEORY AND HYPOTHESES}

\subsection{Rape definition}

In this article, "rape" refers to all cases of complete (sexual intercourse) and incomplete (attempted) rape that have occurred outdoors (e.g. in a street, park, transportation setting), the large majority of rapes that occur outdoors are committed by a stranger to the victim (Chapter 6,1 
$\S, \mathrm{p} 22 ; \mathrm{BR} \AA$, 2012). The Swedish penal code states "a person who by violence or threat which involves, or appears to the threatened person to involve, an imminent danger, forces another person to have sexual intercourse or to engage in a comparable sexual act, that having regard to the nature of the violation and the circumstances in general, is comparable to enforced sexual intercourse, shall be sentenced for rape to imprisonment for at least two and at most six years" (Law 1998:393, Chapter 6 § ; Ministry Justice, 1999).

\subsection{Women's mobility and rape}

Women and men's mobility differ in space (Cresswell \& Uteng, 2008, Loukatou-Sideris, 2016). Women disproportionately take greater responsibility for activities that take place in the private sphere and close to home: childcare, care of the elderly and household chores. They are also more likely to have multiple purposes and multiple destinations within one trip than are men (Kunieda \& Gauthier, 2007, p. 6). It is therefore not surprising that women and men are victimized by crime in different places and during different activities. Regardless of where in a community a woman lives, the home tends to be more dangerous than any outdoor environment, as women are more often victimized by someone they know (Dymén \& Ceccato, 2012). When there is a perception of threat, women create strategies that vary across space or they avoid going out at certain times (Loukatou-Sideris, 2014). However, sexual assault against women in public spaces occurs at all times of day, around the world and, for a variety of reasons and is largely underreported (UN Women, 2014). From those who reported rape, we know that among cases that occur in outdoor environments, the victim is predominantly a young woman. Considerable research has been dedicated to learning about victims, finding a disproportionately high prevalence of having previously experienced psychological problems, psychiatric disorders, substance abuse (alcohol and/or drugs), or previous sexual victimization (e.g. Abbey et al., 2002a,b; Humphrey \& White, 2000; Leifman \& Henriksson, 2013; Rosay \& Langworthy, 2003, Ullman, 2010). Additionally, much criminological research concerning rape has focused on rapists and their modi operandi (for a review, see Ceccato, 2014), finding that alcohol contributes to sexual assault through multiple 
pathways, often exacerbating existing risk, when it is consumed by the offender, victim or both (Abbey at al., 2002b). However, Hewitt \& Beauregard (2014) found recently that rape place factors affect the offender's behavior (serial stranger sexual offenders) more than offense timing. Moreover, they suggested that some outcomes are more dependent on the rape context than the offender and his actions. Yet, relatively little is known about the overall situational conditions where women are most likely to be sexually assaulted in public places.

In this article we use the 'theory knotting strategy' (Ward \& Siegert, 2002) to integrate the best aspects of competing theories and construct new theoretical elements that knit the theories together under a framework that can inform the analysis of situational conditions of rape in outdoor places.

Routine Activity Theory suggests that crime occurs when three elements converge in time and space: a motivated offender, with a suitable target or victim, in the absence of a capable guardian (Cohen \& Felson, 1979). Despite such convergence, rapes do not occur uniformly in all types of public places. A reason is that "motivated criminals do not search through a whole city for targets; they look for targets within their more restricted awareness space” (Brantingham \& Brantingham, 1984:365). Research into the geography of serial rape has found, for instance, that offenders tend to use repeatedly the same geographic space (e.g. Pyle, 1974), a place that they know well. Following Crime Pattern Theory, the awareness space of an individual is composed of their "anchor points" in the urban landscape, such as place of residence, school, place of work, public meeting places and frequently used subway stations and the lines of travel connecting these anchor points. Offenders' awareness spaces overlap with those who may become their victims, for instance, at an anchor point, such as a park on the way home. Even within people's awareness spaces some places are more prone to rape than others. The international literature on sexual violence indicates that rape in public places tends to occur in areas characterized by construction sites, parks, urban renewal and temporary lodgings and in inner city areas close to bars (Canter \& Larkin, 1993; Ceccato, 2014; Ceccato et al., 2016; Pyle, 1974; Rosay \& Langworthy, 2003). Studying a city in Alaska, Rosay and Langworthy (2003) found that sexual assaults correlated 
with the density of bar locations. A shortcoming of previous studies on rape was that they could indicate that "rape places" shared a number of environmental commonalities, but they failed to answer why some places that had those characteristics did not have any rapes or, conversely, why places that did not share those common characteristics still would be a site of rape.

One possibility is that rape is dependent on more contextual factors than any particular setting itself. It is likely that areas with a large number of anchor points will have more rape, but that all other situational conditions of rape must still be in place for a rape to happen. Poor social control in an area, for instance, is one contributing factor that is contextual. Socially disorganized neighborhoods have more crime, including cases of rape (e.g. Amir 1971; Pyle et al. 1974; Maume 1989; Tewksbury et al. 2010). The mechanisms linking socially disorganized residential areas and crime relate to people's inability to exercise social control in their neighborhoods and to solve problems together. Social Disorganization Theory and its modern developments (Shaw and MacKay, 1942 and later by Kornhauser 1978; Sampson, Raudenbush \& Earls 1997) have provided part of the theoretical underpinning for many studies that focus on the impact of area and neighborhood characteristics on crime. For rape, Ceccato et al., (2016) suggested that contextual factors related to opportunity and accessibility must be in place to increase the risk of rape in an area.

The influence of area characteristics on individual behavior depends on a person's mobility patterns, which in turn are affected by temporal and seasonal variations. For rape, Cohn (1993) also indicated that lack of daylight has been predictive of rape. Amir (1971) found that almost half of rapes occurred in the evening and nighttime hours (8:00 p.m. to 2:00 a.m.) and two-thirds of rapes up to the early morning hours (8:00 p.m. to 8:00 a.m.). Also, a quarter of offenses occurred on weekends, often while conducting unstructured activities. These activities are activities performed after e.g., school or work, activities that may not follow a particular rhythmic pattern over time or space, such as leisure activities or vacation. This may explain why seasonal variations seem also to affect levels of rape. Gabor \& Gottheil (1984) found that in Canada the majority of rapes took place during the summer. Still, how do space and time interact to affect the 
situational conditions for rape?

The urban environment does not affect individuals equally. Individuals are mobile and spend time in many environments with differing and variable criminogenic characteristics over time. Situational Action Theory offers a process-based explanation of offending that helps identify the sufficient conditions for a crime to occur. This theory accounts for the mechanisms through which the intersection of individual and setting move individuals to commit crime (Wikström, Ceccato, Hardie, \& Treiber, 2010), and suggests that much offending can be viewed not simply as the product of deep social, economic and psychological causes but also as the result of deliberate choices by individuals. Thus, rape will only happen if the offender feels "motivated enough" (by events that precede the crime) to take advantage of a setting (right place, right time and right person) and consider sexual assault as a possibility. To better understand the role of environment in acts of rape, we need to know more about crime settings, contextual information about the activities and the interactions that occur in social settings before rape takes place. Crucial with this theory is the assumption that it is the mix or intersection of activities, the victim's social interactions (and their contexts) at a particular time that leads a motivated offender to act. This dynamic perspective of Situational Action Theory on crime causation is unique, not offered by any other theory presented so far in this article, and is used here to inform (not test) the analysis of rape. Note however that Situational Action Theory says little about the role of victims, as the goal of the theory is to explain why people commit crime. From the offender's perspective, the theory considers acts of rape an outcome of a perception choice process initiated by the interaction between the individual's crime propensity and his/her exposure to a criminogenic place (some of these issues have already been analyzed in the North American context, e.g. Beauregard, Rossmo, \& Proulx, 2007; Duwe, Donnay, \& Tewksbury, 2008). For our analysis here what is important is that by understanding the whereabouts and social and environmental contexts of women's activities, we can get closer to understanding how the offender chooses a victim. We submit that these factors act in a system of actions and responses that cannot be analyzed in isolation from one another. 
Guided by previous studies of rape and the theories that guide them we hypothesize that:

- Hypothesis 1. The types of places where women spent time just before the event are associated with risk of rape (For reference, see Canter \& Larkin, 1993; Ceccato, 2014; Pyle, 1974; Rosay \& Langworthy, 2003). For instance, higher risk of rape is associated with entertainment areas (e.g., restaurants, clubs, bars, parks, sports events).

- Hypothesis 2. Unstructured/leisure activities, typical of nights, weekends and vacation times, are linked to an increased risk of rape (e.g., Amir, 1971; Cohn 1993; Gabor \&Gotheil, 1984; Rosay \& Langworthy, 2003). Higher risk of rape is associated with drinking alcohol and/or taking drugs before the event. To help operationalize this information to carryout analyses, we refer to these as activities.

- Hypothesis 3. The victim's social context, the woman's social interactions (or being alone) prior to the rape plays a role in the risk of rape (e.g., Leifman \& Henriksson, 2013; Rosay \& Langworthy, 2003, Ceccato, 2014). Being alone or among nearly acquainted individuals can be riskier than being around friends. We refer to this domain as risky social interactions.

\section{THE STUDY SETTING}

The study is set in the Swedish capital, which constitutes an interesting study setting. This Scandinavian county has the highest rape reporting figures in Europe but one of the lowest conviction rates (Lovett \& Kelly, 2009). At the same time, it has a strong reputation and a long tradition for addressing violence against women, which partially explains the high reporting rates. For instance, the Kvinnofrid law (Violence Against Women Act) of the 1990s and the most recent changes in the penal code, since the mid-2000s, have created a platform for action that was previously nonexistent. Moreover, this study is part of a larger research project - the Stockholm rape study, funded by the Swedish Research Council FORMAS - that has as a main goal to assess the spatial dynamics in which outdoor rapes take place, including women's whereabouts before a rape.

Stockholm County, the study area, has 2.1 million inhabitants. This area is an archipelago with http://mc.manuscriptcentral.com/jiv 
a well-functioning transportation system composed of bridges, roads and efficient public transportation, with a subway network, trams, commuter trains and buses. An estimated 700,000 people travel by public transport in Stockholm every weekday, and more than a third of these pass through the main central station.

In Stockholm, as in Sweden as a whole, theft, vandalism and alcohol and drug offenses are the most common types of recorded crime. The Stockholm safety survey shows that the majority of the adult population in Stockholm city does not worry about being a victim of crime although crime events tend to happen more often in Stockholm municipality than elsewhere in the country (Ceccato, 2016). Women (22\%, compared to $15 \%$ of men), the disabled and the elderly are significantly more fearful than the rest of the population (Stockholm Municipality, 2011).

Researchers have long suggested that women's fear of crime reflects the fear of being raped (e.g. Hirtenlehner \& Farrall, 2014; Warr, 1985). Yet, rape is one of the least reported crimes in Sweden (23\% of sexual offenses), and the majority of cases that reach court result in acquittal (BRÅ, 2014; BRA, 2005). While police reports of sexual offenses have increased over several decades, the national victims' survey shows that the proportion of people reported to have been victims of sexual offenses remained relatively stable, representing approximately $0.8 \%$ of all respondents (BRA, 2011). Young men dominate the statistics as suspects (98\% in 2011), while young women are overrepresented as victims. Police records show significant increases in cases of rape since 2005, largely attributable to changes in sexual offense legislation in the mid-2000s. The effects of those changes are seen in the number of rapes reported in 2005-2011. In 2013, legislation on sexual crimes was tightened again, and rape was expanded to include cases where the victim responds with passivity (BRA, 2014). In Sweden, every case of sexual violence is recorded separately, which means that the official statistics tend to be high for the country and cannot easily be compared internationally. Being raped twice by the same person (regardless whether it is in the same night or a week apart between events) counts as two offences in Sweden whereas elsewhere this may be counted as one event. Swedish police-recorded data shows 63 rapes per 100,000 inhabitants in Sweden in 2010, and according to Lovett \& Kelly (2009) the 
Swedish rape rate has being one of the highest of any country in Europe. The Swedish rape rate was three times higher than the number of cases in the same year in Sweden's neighbor, Norway, and twice the rate in the United States and the United Kingdom. In Stockholm municipality, rapes are recorded by the police about 150 times a year; $30 \%$ constitute rape attempts. About half of these cases seek help in the Emergency Clinic for Rape Victims, which is the first of its kind in the country. The clinic is open 24 hours a day and admits women who have suffered acute sexual assault.

The sample of victims of rapes studied here is dominated by young women (median age 21 years, range 14-60 years). As international literature suggests, this group of women is characterized by a number of vulnerabilities and may not be representative for all raped women, including those who chooses not to seek the emergency or report it to the police (for a complete discussion general reference of risk factors for sexual abuse, see Ullman, 2010). For instance, four of every 10 subjects $(41.4 \%)$ reported having a history of sexual violence prior to the rape (though it is unknown whether the previous violence was caused by people the women knew or strangers). Teasdale, Daigle, and Ballard (2014) when reporting risk factors specifically for repeat victimization suggest that repeat violent victimization is not uncommon among victims of violence who have psychological problems and/or a history of substance abuse. In the case of Stockholm, although not all cases refer to repeat victimization as in the case of Teasdale et al. (2014), 4 of every ten women were victims of rape and show a number of other vulnerabilities: $40.4 \%$ declared previous addiction ( $9.6 \%$ currently had an addiction), which is a much higher percentage than among the remainder of young women in the population who declared using drugs, especially cannabis (14.5\%, see Leifman \& Henriksson, 2013). One in five declared having been diagnosed with psychiatric disorders, ranging from depression, ADHD and bipolar, to eating disorders, and a few resulting in suicide attempts. The vulnerability of this group of women is also indicated by the fact that $46.0 \%$ of all those who sought help had been using psychotropics at that time of the rape. Moreover, more than half of women (63.5\%) declared having alcohol during the day/night of the rape (the exactly amount is unknown), whereas few had used other drugs (3.4\%). 


\section{DATA AND METHODS}

\subsection{Data acquisition}

The analysis is based on 147 medical records of women victimized by rape (or attempts of rape in 19,7 per cent of cases) who sought help at the Emergency Clinic for Rape Victims (outpatients) at the Karolinska Institute in 2012 and 2013. This clinic is the only clinic specialized in taking care of rape victims in Stockholm. These records provide an account of the location and nature of women's activities on the day of the rape as well as information about these patients (age, place of residence, psychiatric anamnesis (data come from medical records, not based on women's recollection), current psychotropics (data come from medical records), current and past addiction, previous history of addiction, previous history of rape, drunk and/or under the influence of a substance. The dataset was obtained with the approval of the Stockholm Ethical Review Board in late 2013. Initially, a number of semi-structured interviews were planned to be performed with victims of rape (3 months after the event occurred, a time threshold imposed by the doctors). However, to recruit women for the interviews turned out to be a difficult task, as many of those who contacted doctors were declared unfit to take part in the interviews for psychological reasons even after 3 months of the rape. From an initial sample of 50 women, only 3 agreed to be interviewed. Women did not answer after consecutive invitations made by letter, email or telephone. Most of them would decline to take part of the interview for different reasons; some were in treatment or just moved from Stockholm and therefore uncontactable.

As a result, our analysis was based primarily on the information written medical records of the 147 women, particularly the field "free-text", in which the doctors describe in detail the sequence of events, over time (149 records were initially available, 2 were excluded because they did not contain a minimal information about the case, such as information about the victim, their activities and whereabouts). The medical description is a rich and often long text field (from several hundred to thousand words) that provides information about the victims' whereabouts, with whom she spent time and her activities. Seven was the minimum number of steps or stations that were identified in medical records but in 17 per cent of cases, some of the information were left empty 
since the records failed to be reported on, for instance, what they were doing at a particular time. In another cases, the same activity was repeated when there were indications that the activity happened over a long period of time, such as over an afternoon party. Digital land-use data was used to recreate the activity paths taken by women victims of rape. The GIS layers were obtained from the Stockholm City technical office and Growth, Environment and Regional Planning (TMR). Despite the fact that some records were more complete than others, they all followed a sequence of events that were later broken down into stations, and linked to activities and social interactions of the victims, which is now explained in section 4.2.

\subsection{Data preparation and pre-analysis}

After extracting data from the medical records, text records were transferred to a spreadsheet to develop a space-time budget for each individual (for other examples see e.g. Bernasco, Ruiter, Bruinsma, Pauwels, \& Weerman, 2013; Wikström, Ceccato, Hardie, \& Treiber, 2010, Wiebe et al. 2014). Information was classified according to four subsets: characteristics of the individual; data on the woman's activities; the space/settings in which the woman spent time; and information about women's social contexts and interactions, regarding who the woman was with at that particular time or station (defined below).

Instead of using the common notion of time, chronos, this study applies the notion of time as kairós to record time in a space-time budget for the analysis of the situational conditions of rape. The term kairós in Greek is defined as "time, place and circumstances of the subject," a conceptualization of time that fits medical data used in this analysis, based on events recalled by women and highly dependent on their memory of what happened during the traumatic event. While the description of time in kairós is not mechanical or chronological, as it is in chronos, the time conception in kairós is the one that goes fast or slows down, omits parts and jumps but still is regarded as "the proper time" by the subject (Czarniawska, 2004). This suits the original medical reports which are based on descriptions of circumstances by time that are dependent and influenced by each woman's capacity to recall the events experienced during the rape. Thus, 24 
hours of the day were centered on the rape event, but the experienced length of activities preceding the event varied by individual. To allow comparisons between individuals before and after the rape, the concept of "stations" was created to indicate the logical and unique sequence of activities as 'steps' (e.g., waking up comes first and then brushing the teeth comes second) as reported in the medical records. Note that the type of activity and the sequence are unique for each person, accommodating different ordering (e.g., eating with friends can be station 2 for a person but station 4 for another) and repetition (e.g., drinking home, eating out, drinking with friends). Women's mobility was broken down into time blocks representing seven steps, or stations, before and after rape, with their actions, social interactions and places visited pre-event, event and post event. Seven was the minimum number of steps or stations that were identified in medical records. For activities, these stations could appear as follows.

1. Preparing to go out (pre-rape)

2. Eating out with friends (pre-rape)

3. Social interacting in a bar (pre-rape)

4. Traveling by train (pre-rape)

5. Attacked and raped (rape)

6. Calling for help (post-rape)

7. Going to hospital (post-rape)

Later, place, activity and social interaction were further classified by levels of generalization for pre-rape, rape and post-rape. In social interaction, a woman could declare 'being alone' (nobody around or with people around that are unknown to her) or having company (people she knows), here social interaction is about women's social context. If she was alone in a bar with many people around, that was counted as alone in a bar.

In the case of activities, three levels of detail were adopted (Figure 1), from detailed (level 1) to general (level 3). The advantage of using these steps is the fact that the data is time-independent, because the phases revealed the pre-conditions of rape, the moment of rape and post-rape conditions. Thus, a woman raped in the early evening could with no problem be compared with 
one raped in the early morning.

Based on more than 8 decades of studies of rape, a selected number of 'risky dimensions' were created for place, activity and social interaction. Risky places were, for instance, parks/forests, bars, tunnels/stairs/ditches or alleys, while activities included feeling dizzy and drinking, and risk social interaction comprised being alone, during the night. The combination of activity, social interaction and place - "the risky mix" - is expected to capture an individual's highest likelihood to be raped.

\subsection{Visualization of situational conditions of rape in VISUAL-TimePAcTS}

We used VISUAL-TimePAcTS as a tool to visualize and identify patterns and sequences of activities of women over time and space as an aid to analyze the situational conditions of pre- and post-rape (Vrotsou, Ynnerman \& Cooper, 2014; Vrotsou, Ellegård, \& Cooper, 2009). The tool also provides functionality to interact and explore different aspects of the collected event sequences. Inspecting patterns of activities in time and duration in this data sample gives rise to hypotheses on the temporal relations of these activities regarding the outcome of rape that should be investigated further through modeling.

\subsection{Modeling rape in case-crossover design}

Situational factors were assessed by looking at variation over time (how factors varied across the seven stations), setting, activity and social interaction. Then the study hypotheses were tested using a case-crossover study design as a way to identify factors that pose a risk or are protective against rape. This was accomplished by treating each study participant both as a case subject and as an individually matched control subject (Maclure, 1991). Specifically, the data are arrayed such that each woman is classified as case subject at the time of or shortly before the outcome (rape) occurred; each woman is also classified as a control subject at separate times prior to the time the outcome occurred. Using the nomenclature defined above, station 5 is when the rape occurred (case period), and times shortly before the rape occurred (stations 3 and 4) and times early in the data (stations 1 and 2) are used as the two control periods. In this way, the approach compares situational characteristics and behaviors at the time shortly before the rape occurred versus earlier 
in the day.

The analysis is conducted with conditional logistic regression to achieve a within-subject comparison. Specifically, for each subject, whether the subject was exposed to a given situational or environmental characteristic at the time of (or just prior to) being raped is compared to a time point earlier in the day, when again we assess whether the subject was exposed to the same characteristic. Finding that the prevalence of a characteristic (i. e., the prevalence of exposure) is more common during the rape than earlier is evidence that the characteristic is associated with the likelihood of being raped. The resulting odds ratios provide the measure of the relative prevalence of characteristics at the time of the outcome versus earlier in time. An odds ratio of 1 is the null value. A value greater than 1 indicates that a characteristic posed a risk for rape, and a value less than 1 indicates that a characteristic was protective against rape.

\section{RESULTS}

\subsection{The spatial-temporal context of rape}

More than half of the women who sought help at the hospital declared having been raped during the darker hours of the day, that is, $18.00-23.59$ hours $(18.1 \%)$ or $0.00-5.59$ hours $(53.7 \%)$, which fits the period of unstructured activities/leisure hours. The majority of the rapes occurred during the warmer months of the year, October (18.5\%), August (13.0\%) and July (11.6\%), in other words, summer and autumn.

The most common setting in Station 1 was indoors. For following stations, the most common location where women spent time on the day of the rape was a street setting $(23.8 \%)$, forested areas/parks $(16.8 \%)$ and public transportation $(16.8 \%)$. The station during which rape occurred was most frequently in forested areas $(27.1 \%)$, vehicles/taxis $(20.8 \%)$ and street settings/secluded pathways (17.4\%). Paradoxically, medical records indicate that in some cases women decided to take a taxi home because they believed it to be safer than public transportation (note that the metro stops running around 2 a.m. and is replaced by various infrequent bus lines during the night). Safety was one reason to take a taxi but not the only one; other reasons included feeling 
unwell or depressed after an unpleasant event that night. Note that of 35 cases, only two took place in the afternoon, the great majority occurring after midnight. Since one quarter $(25 \%)$ of the rapes occurred relatively close to women's homes (within $3.2 \mathrm{~km}$ of the victim's home), and half occurred far from home (beyond $9.6 \mathrm{~km}$ of home, when women live in the outskirts but was raped in the city center, for example), we used VISUAL-TimePAcTS to explore potential differences between these cases (Figure 1)

Figure 1 - about here.

The activities are ordered along the x-axis, sorted by day of week. Time is represented on the yaxis going upward and spans 24 hours, from noon to noon the following day (12:00-12:00). The rape-related activities (drawn in red) show a larger concentration of occurrence during the early morning hours after midnight (denoted by a black horizontal line across Figure 1) in both sub-sets (close to and far from home). In the representation of women raped far from home (Figure 1(b)), there are longer periods of social activities (drawn in purple) preceding the rape, primarily on Sundays, Thursdays and Saturdays. Following principles of routine activity, the group of rape (b) most often happens in inner city areas, where entertainment venues, bars and restaurants and Stockholm night life are concentrated, while the rapes that happen closer to home (a) are associated more often with everyday life activities, from school, work and sport and leisure activities, to the home or women's family residence.

\subsection{Women's activities before and after the rape}

More than half of the women used alcohol (60.4\%) during the first stations at the day of the rape. Alcohol use was uncommon after that and less common during each successive station. The case of Emma (fictitious name) shows an example of the sequence of events when alcohol was present:

Emma was out at night at a bar in town together with friends. She was thrown out by bouncers when she got too drunk (...) Emma decided to take the subway home and went to the subway station. She noticed in the subway a man sitting just behind her, and she felt uncomfortable. (...) Emma got off at her subway station and knew quite quickly that the man she had seen on the subway was following her. She tried to tell him repeatedly, 'Leave me alone, go 
away!' (...). At last, Emma reached the gate and opened it, but the man put his foot in the gate and managed to pull her out and to the ground and pressed her up against the wall. What she remembers is that she curled up on the ground and covered her legs but he managed to get a hand inside her panties. (Emma, 30 years old).

Figure 2 displays the results of the activity representation of the raped women cluster with regard to how the activity sequence "drinking followed by rape" appears in the data. This activity sequence is common among the collected activities and appears in 81 out of the 147 representations for the women of this study. Alcohol use was identified in all seven time stations of analysis. The software uses a k-medoids clustering approach, which means that the user has to define the number of clusters as output (namely a number of different alternatives have been tested and it was found that for the current data 4 clusters was producing better results). The quality of the clustering for each alternative was assessed visually by inspecting the results in the visual interface and by computing a quality metric using an absolute error-criterion. The process indicated that choosing $\mathrm{k}=4$ resulted in more concise clusters in terms of the temporal distribution and duration of the chosen activity sequence and also in terms of the characteristics of the women in each group. Less than 4 clusters did not provide enough separation between the groups while having more than 4 did not improve the results further but rather split up the already sufficiently homogeneous clusters into smaller ones with marginal differences between them. Two of the clusters that emerge are quite distinct and merit closer study. These are the third and fourth clusters shown in Figure 2. The third cluster displays drinking activities starting before midnight and spanning longer periods and rape activities occurring soon after the drinking activity has concluded. The fourth cluster, on the other hand, displays shorter sessions of drinking activity occurring primarily before midnight and longer temporal gaps on average between the drinking activity and the rape activity. These clusters give rise to hypotheses concerning the temporal relations of these activities that were further investigated in sections 5.4 and 5.5, namely the importance of patterns of alcohol consumption patterns and rape.

Figure 2 - about here

Many of the women had a previous history of rape. The number is especially large in clusters 2 http://mc.manuscriptcentral.com/jiv 
and 4: 12 of 21 women in cluster 2, and 10 of 23 women in cluster 4. The majority of women in clusters 1 and 2 had a history of addiction ( 9 of 18 in cluster 1, and 15 of 21 in cluster 2), but none of the clusters display patterns of current addiction, though single exceptions appear in the data (1 woman in clusters 1 and 2, none in clusters 3 and 4). Most women in clusters 2 and 3 have psychiatric anamnesis, while the majority of the women in the clusters do not display current psychotropics. Most rapes occurred far from home and the majority in clusters 3 and 4 occurred close to the city center.

\subsection{Women's social context before and after the rape}

The descriptive statistics show that in pre-rape stations, women were most commonly with close acquaintances, family/friends (56.9\%) earlier in the day (pre-rape 1 or 2 ) as opposed to later in the day, or alone $(34.0 \%)$. The offender was present very rarely $(3.5 \%)$. Then, in post-rape stations, women were less likely to be with close acquaintances $(24.5 \%)$ and more likely to be alone (37.1\%) and almost equally likely to be with the offender (34.3\%). Half of the victims (50.0\%) had spent time in the same location as the offender earlier in the day, and most $(76.0 \%)$ of the victims had been with the perpetrator shortly before the event. $19.5 \%$ had been alone shortly before the event.

Vehicle rape seems to be associated with some planning by the offender (who may have used the same tactics before), by which he identifies the potential victim at an early stage, perhaps before the woman enters the car. Note that in 35 cases of rape associated with "cars," women declared feeling ill, for instance, dizzy, drunk or confused, which made them decide to take a taxi. After some time they were raped. The perpetrator's identification of the potential victim may go hand-in-hand with unplanned circumstances that women are found at that moment, which favor the offender. According to the medical reports, in some cases offender's actions when she was already in the car put the woman in a place in which compliance was the only way to get out of the situation:

Anne separated from her friends as they had a quarrel. Alone, she felt better taking a taxi home (...) She 
jumped into one, unclear which company it belonged. She discussed the price with the taxi driver, and they went off at about 3:45. Anne sat in the back seat and was still crying because of the fight. The taxi then drove "the wrong way" (...) and stopped after about 10 minutes. She looked after the driver's ID card, where taxi drivers usually have them, but saw nothing and was even more frightened. The driver moved to the back seat and lock the doors (...) She was very afraid that he would become violent. He said, "Just do it, then I will take you home." The man held her during the vaginal penetration (...) (Anne, 21 years old).

\subsection{Women's settings before and after the rape}

Table 1 reports results of the case-crossover analysis investigating whether any of the types of places where women spent time were associated with an increased or decreased risk of sexual assault. Rape was significantly less likely to occur at a time when women were in a private setting $(\mathrm{OR}=0.05)$ or in a street setting $(\mathrm{OR}=0.50)$, compared to when women were in an indoor public setting (reference category). Alternatively, other places posed increased risk for sexual assault.

Specifically, rape was significantly more likely to occur at a time when women were in a forested area $(\mathrm{OR}=7.00)$, in an interstitial area $(\mathrm{OR}=7.00)$ or in private transportation $(\mathrm{OR}=5.25)$ than when they were in an indoor public setting. The risk of rape was not different in other outdoor settings or in public transport, compared to indoor public settings. Note that private transport means "taxis" or illegal taxis that women take to go home, while public transport involves the subway, commuter trains, buses and trams.

Table 1 - about here.

\subsection{Is there a "risky mix"? Activity, social interaction and settings}

By analyzing the victim's whereabouts, the activity the victim performs and with whom she socializes with just before the rape- combined - we can get closer to understanding how and when the offender attacks (and when it chooses not to). Other visual analyses (not shown in Figures 1 or 2) were conducted by arraying the data in sequence according to the seven stations that defined the different periods of the day. Within each station, the proportion of the time that women spent engaged in activities or settings that were classified as high risk, or "risky" with respect to the http://mc.manuscriptcentral.com/jiv 
possibility of rape, was calculated. This way, we found that the proportion of time spent in an activity and in a social setting increased during each successive station of the day to a maximum at the time the rape occurred. Then, being in risky social setting was considerably less common, as expected, after the rape occurred. For example, the prevalence of alcohol use on the day of the rape was common but that consumption most often seemed to occur relatively early in the process. Overall among the 147 women, 64.6\% drank alcohol (to a much less extent drugs) at some point at the day and $35.4 \%$ of women did not ingest any substance. We proceeded with the analysis of women who never drank alcohol before being raped and a separate analysis of those who did drink alcohol, to assess the importance of place, activity and women's social context on rape. A key finding here was that for both categories, the results are very similar to the total sample of women overall.

\section{Table 2 - about here}

Table 2 shows that for all women in the sample overall, social context significantly increased the risk of rape $(\mathrm{OR}=10.3)$ as well as did particular types of activities $(\mathrm{OR}=3.4)$ but relatively not place. The second section of Table 2 indicates that for women who did not drink alcohol at the day of the rape, "place" was, again, not associated with rape, but "social context" $(\mathrm{OR}=26)$ and "activity" were $(\mathrm{OR}=5.6)$. This reveals that certain situational conditions can increase the risk for rape even if women have not consumed alcohol. The third part of Table 2 reports that neither activity, social context (except being with the potential offender), nor places were associated with the higher risk of being raped among women who had consumed alcohol. Note that both for women who had and for those had not consumed alcohol, being "with close acquaintances" was a strong factor that protected them against such sexual violence As soon as they are no longer around, the risk increases.

\section{DISCUSSION OF THE RESULTS}

Rapes happen more often during the evening and night especially during the warmer months of the year, which fits the period of free time, leisure and vacation. Police-recorded rape in http://mc.manuscriptcentral.com/jiv 
Stockholm shows similar temporal patterns (Ceccato, 2014), which is not surprising because individuals who seek help at a hospital are encouraged to report to the police and vice-versa. A similar temporal pattern has also been identified and predicted by the international literature (e.g. Amir, 1971; Cohn, 1993; McDowall, Loftin, \& Pate, 2012). In this sample, rape was most frequently in forested areas, street settings (secluded path ways) and in vehicles/'taxis'. Forested areas are in line with previous studies (BRÅ, 2005; Ceccato, 2014), but not vehicles/taxis.

The relatively large share of rape in "taxis" (or a man with a vehicle pretending to be a legal taxi) was a surprise in these medical records and was not initially hypothesized. One reason might be that a rape that happens in a car parked in the street may not be considered by police officers who register the offence as a public place. Interestingly, rapes in vehicles, in this case a "taxi” (illegal taxi), private cars or boats are not as visible in police statistics as they are in these hospital records, which raise a number of questions about the comparability of medical records and police rape statistics. This mismatch also brings about issues of why women do not report when the assault happens in a taxi but do report if it happens in other public settings. A possible explanation is that women do not report rape in vehicles because they blame themselves or feel ashamed for accepting the ride with a complete stranger in the first place, even if they were convinced that it was "a normal taxi". However the characteristics of these rape places alone are not enough to inform why these places were chosen, therefore we need to combine information about individuals' activities and social contexts at a given time.

Findings show that a considerable proportion of time in the early stages of the process that led to rape was spent in particular types of activities and social settings (see section 5.5 for more details). The proportion of time spent in a particular activity and in a risky social setting increased during each successive station of the day, to a maximum at the time the rape occurred. These findings corroborate therefore hypotheses 2 and 3. However, the odds ratios for women's social context and risky places were greater than 1 but not at a level that reached statistical significance. Findings showed also that the prevalence of alcohol use on the day of the rape was common but that consumption most often seemed to occur relatively early in the process. It may also be that 
women were not asked whether or not they stopped drinking, or for how long they consumed alcohol, which means that the data is merely an indication of when they started drinking alcohol on the day of the rape. Alternatively, it could indicate that a considerable time lag occurs before the initiation of alcohol consumption and the onset of the rape event. More interestingly, the results were similar between those women who never drank alcohol at the day of the rape and to what was observed in the sample overall, which indicates that social interaction and activities make independent contributions to the risk of been raped.

On top of these individual factors, then, these findings indicate the importance of women's mobility and social interaction over time and space to explain the variation of rape victimization. This is not the same as to say that risky places are not important. Using the indoor public setting as the basis category, results show that being outdoors in general is not risky for women. As suggested in hypothesis 1 , some public environments are actually protective, such as being in open streets, while others, riskier. The risk of rape is increased in particular land uses such as forests/parks, interstitial settings, secluded paths and, surprisingly, being with a man in a car that the woman has believed is a taxi. Although most rapes take place in certain types of public places (e.g. forested areas), this does not mean that all public places are more dangerous than the rest of city, quite the opposite, for certain types of environments, women are more protected than elsewhere. Although these findings are a bit surprising, one should recall that there are different types of "streets" and levels of guardianship associated to them. In this study we split street from pedestrian paths. A secluded pedestrian path should be more prone to rape (because of the anonymity that it allows) than a street, where cars and people may pass by more frequently. These findings exemplify how different micro-outdoor environments have a different impact on the risk for rape. Most importantly, other situational conditions (types of activities carried out by women, social interaction) must be in place for crime to occur.

\section{CONCLUSIONS AND IMPLICATIONS}

For all 147 women from the Stockholm sample dataset that reported rapes to hospital, the http://mc.manuscriptcentral.com/jiv 
situational conditions before the event, particularly social context and activity, increased the risk of rape. Results of this type, call for new research on the necessary conditions of rape beyond offenders and victims; some suggestions for future research questions are discussed in the following paragraphs.

There are a number of implications in these findings for criminological theory. This study adopted the 'theory knotting strategy' (Ward \& Siegert, 2002) to integrate the best aspects of competing environmental criminology theories, namely routine activity, crime pattern theory, social disorganization and situational action theory, into one framework. This strategy has shown to be successful for this case study because - together - they incorporate the necessary elements for the study of rape, yet particularly credit is given to situational action theory. Although traditionally used to explain why individuals commit crime (offenders), Situational Action Theory has proved useful for enlightening the analysis based on women' narratives before and after the rape, therefore the theory can also support the analysis of victims of rape. For example, in the past environmental criminology theories had individually neglected the relevance of events that precede crime and the dynamics of its space-time dimension. Individuals are exposed to different environments when moving, their victimization vulnerability to crime also varies, as do offenders' motivations.

We found that the combination of medical records, visualization techniques, space-time budget and statistical modelling helped generate new insight into the situational conditions of rape. Note that an advantage of case-control modeling approach used here, which compares subjects at the time of rape to themselves at earlier time points, is that treating each subject as its own control serves to control for any potential confounders that are characteristics of the participants, including those that may be difficult or impossible to measure (e.g. impulsiveness). An alternative study design could be accomplished by conducting a case-control study, where each cases at the time of assault is compared to a control subject who was not assaulted. In such an approach, however, it can be difficult or not possible to adequately control for ways that cases and controls may differ. The case-crossover approach had advantages for the study carried out 
here.

This study has limitations. The limited sample of medical records does not reflect the whole population of raped women in Stockholm (half of the total reported by the police). This means that findings from this study cannot be generalized to all women who experience rape, only to a specific subpopulation that report rape to hospitals. Although there are similarities between present results from this sample and findings from previous literature, this distinction may explain some differences in results related to the types of activities and social interaction before the rape. According to the rape literature, it is likely that many more rapes are unreported (Lovett \& Kelly, 2009). This sample covers most likely cases related to the dynamics of night life in the weekends and less of those that happen in the outskirts of the city (Ceccato, 2014), with potentially different modus operandi. Another issue with this sample is that according to Ullman (2010), women who report to formal sources including hospital staff, are not representative of all women who are victimized as they tend to have experienced sexual assault before. In the Swedish sample, however, 40 percent have been victimized before. Another issue refers to the variability of the information contained in the medical records, particularly how much detail, accuracy and meaning could be gleaned by the medical records of these events. Some of these records were extremely detailed; others offered just a superficial account of the rape, enough to be translated into the sequence of activities for our analysis. The variability of information contained in the medical records reflects both women's ability to recall the events as well as medical doctors' willingness to take time to write them down. Another limitation is the potential bias involved in women's recall of sequence and timing in terms of how long after the rape the women's records were taken.

This study has made a unique contribution by examining the situational conditions of rape systematically over time and space - before and after the event - nothing similar is found in previous international literature. Thus, despite the limitations of this study, there are implications of these findings that are relevant for rape prevention. First, these results imply that situational crime prevention must be sensitive to space-time variations in human activity that are relevant to crime, which were found here to pertain to aspects of social contexts and place-based settings. 
This evidence calls for new consideration how to develop interventions to break sequences of events that appear to be disproportionately associated with rape.

Second, the presence of alcohol consumption in the stations/settings before the event calls for new multi-pronged approaches to rape prevention. There is also a growing body of research about alcohol and sexual violence (Abbey, 2002; Abbey et al., 2002; Basile, 2015; Gervais, DiLillo, \& McChargue, 2014, Homel et al., 1997) that can be informative for prevention of sexual assault. Rape crime prevention requires the engagement of multiple actors, some beyond the traditional core of crime prevention. Educational programs for bouncers and guards could certainly affect the number of individuals that are put on the street when under any substance (they could instead make sure they are not left alone by contacting acquaintances at the bar, parents at home). Moreover, the improvement of surveillance and guardianship, by police officers, place managers in rape hot spot areas, would certainly make it more difficult for offenders to act. Particular parts of the inner city are the places where young women are chased by men in cars offering "taxi services.” In order to reduce risks, mandatory clearing employment procedures by taxi companies would be desirable.

Third, outside the inner city areas, the role of place managers and their potential to exercise guardianship must also be discussed in relation to the way public grounds are used by the community (e.g. school grounds after school hours). As the risk of rape increases in particular public places, the role place managers and overall maintenance of these places is fundamental. Yet, rapes happen when women are on the move, which calls for a multi-pronged approach to combat rape, door-to-door. For instance, women's safety at subway stations is the responsibility of transportation companies, but the challenge is also to identify who is responsible for women's safety outside these transportation nodes. In Sweden, this unclear assignment of tasks between sectors creates a 'gray zone' of action in which few actors are willing to take charge and share costs beyond their predefined roles. Sweden is not alone; transit agencies around the world do not develop particular programs targeting the safety of women passengers (for a review see, Loukaitou-Sideris, 2016). In addition of the practical difficulties of ensuring safety for women 
using a whole journey perspective, there are important issues that are of more structural nature and perhaps lie outside the scope of this article, namely expected sexual behavior of boys and girls and taboos in sex education in modern multicultural societies. A crucial question that has to be tackled in the future is that why women still cannot travel on public transportation without being at increased risk of rape or afraid of being sexual assaulted? As Phumzile Mlambo-Ngucka, Executive Director of UN Women, wrote: “we have to work with communities to change harmful social norms and attitudes, and social institutions that discriminate and tolerate violence against women" (UN Women, 2014). What this research draws attention to are the types of environmental or situational circumstances that increase or decrease a woman's risk of becoming a target of rape. Despite limitations, this study takes the first steps to illustrate how knowledge of the space-time situational conditions of sexual assault are relevant to inform research and practices towards women's safety in public places.

\section{Footnote}

${ }^{1}$ Any individual aged 13 years old and older can seek care at the Emergency Clinic for Rape Victims at hospital Karolinska Institute within a month the assault happened. This center opened in 2005, and at that time the focus was on female victims of sexual assault, but since 2015 the center is open for all individuals, regardless gender belonging or gender identity. When a person arrives at clinic, (s)he meets with personnel, who ask them to describe what happened. It's important to determine whether (s)he was injured during the assault. Depending on the information (s)he provides, the doctor decides which tests could be. A complete gynecological examination isn't always needed, but it is important that evidence of the assault is not lost so tests are taken. For this reason, (s)he'll be given a second appointment in a couple of weeks for a medical follow-up. (S)he is asked whether (s)he would like to talk to a psychologist or social worker. Doctors won't force the individual to report the assault to the police, but they encourage to do so since it can help with the after rape process. This is not something doctors do at the 
hospital, but they can help (s)he get in touch with the police afterwards. In many cases, individuals are brought to the hospital by police officers after a police report. The medical examination is completely voluntary, and a person can let doctors know at any time if there is anything she or he doesn't feel comfortable with and (s)he would like to stop the examination.

\section{REFERENCES}

Abbey, A. (2002a). Alcohol-Related Sexual Assault: A Common Problem among College Students. Journal of Studies on Alcohol and Drugs, 14, 118-128.

Abbey, A., Zawacki, T. M. A., Philip, O., Buck, M. A., Clinton, M. A., \& McAuslan, P. (2002b).

Alcohol and Sexual Assault Retrieved from http://pubs.niaaa.nih.gov/publications/arh25-1/4351.htm

Amir, A. (1971). Patterns in forcible rape. Chicago: University of Chicago Press.

Belknap, J. (1987). Routine activity theory and the risk of rape: analyzing then years of national crime survey data. Criminal Justice Police Review, 2, 337-356.

Basile, K. C. (2015). A Comprehensive Approach to Sexual Violence Prevention. New England Journal of Medicine, 372(24), 2350-2352.

Beauregard, E., Proulx, J., Rossmo, D.K. (2007). A descriptive model of the hunting process of serial sex offenders: a rational choice perspective. Journal of family violence, 22, 449-463.

Bernasco, W. I. M., Ruiter, S., Bruinsma, G. J. N., Pauwels, L. J. R., \& Weerman, F. M. (2013). Situational causes of offending: A fixed-effects analysis of space-time budget data. Criminology, 51(4), 895-926.

Brantingham, P., \& Brantingham, P. (1984). Patterns in Crime. New York: Macmillan.

BRÅ, Brottsförebyggande rådet (2005). Våldtäkt: En kartläggning av polisanmälda våldtäkter. Stockholm: BRÅ.

BRÅ, Brottsförebyggande rådet (2011). The national victims survey. Stockholm: BRÅ.

BRÅ, Brottsförebyggande rådet (2012). Kodning av brott (11 ed., pp. 100). Stockholm: BRÅ.

BRÅ, Brottsförebyggande rådet (2014). Våldtäkt och sexualbrott. Retrieved from http://mc.manuscriptcentral.com/jiv 
https://www.bra.se/bra/brott-och-statistik/valdtakt-och-sexualbrott.html

Canter, D., \& Larkin, P. (1993). The environmental range of serial rapists. Journal of Environmental Psychology, 13, 63-69.

Ceccato, V. (2014). The nature of rape places. Journal of Environmental Psychology, 40:97-107.

Ceccato, V. (2016) Rural crime and community safety. Abingdon, New York: Routledge.

Ceccato, V., Haining, R., \& Li, G. (2016). The ecology of outdoor rape in an urban area: a Swedish case study. Urban Studies, (submitted).

Chappell, D., Geis, G., \& Fogarty, F. (1974). Forcible Rape: Bibliography. Journal of Criminal Law and Criminology, 65, 248-263.

Cohen, L. E., \& Felson, M. (1979). Social change and crime rate trends: A routine activity approach. American Sociological Review, 44, 588-608.

Cohn, E. (1993). The prediction of police calls for service: the influence of weather and temporal variables on rape and domestic violence. Journal of Environmental Psychology, 13, 71-83.

Cresswell, T., \& Uteng, T. P. (2008). Gendered mobilities: towards a holistic understanding, in T. P. Uteng and T. Cresswell (eds), Gendered Mobilities, London, Ashgate, 1-14.

Czarniawska, B. (2004). On Time, Space, and Action Nets. Organization, 11(6), 773-791.

Dymen, C., \& Ceccato, V. (2012). An international perspective of the gender dimension in planning for urban safety. In V. Ceccato (Ed.), The urban fabric of crime and fear (pp. 311-341). Dordrecht, Heidelberg, New York, London: Springer.

Gabor, T., \& Gottheil, E. (1984). Offender characteristics and spatial mobility: An empirical study and some policy implications. Canadian Journal of Criminology, 26, 267-281.

Gervais, S. J., DiLillo, D., \& McChargue, D. (2014). Understanding the link between men's alcohol use and sexual violence perpetration: The mediating role of sexual objectification. Psychology of Violence, 4(2), 156-169.

Hewitt, A., \& Beauregard, E. (2014). Sexual crime and place: The impact of the environmental context on sexual assault outcomes. Journal of Criminal Justice, 42(5), 375-383.

Hirtenlehner, H., \& Farrall, S. (2014). Is the 'Shadow of Sexual Assault' Responsible for Women's Higher Fear of Burglary? British Journal of Criminglogy. 
Homel, R., Hauritz, M., Wortley, R., Mcllwain, G., \& R., C. (1997). Preventing-alcohol related crime through community action: The surfers paradise safety action project. Queensland: Griffith University.

Humphrey, J. A., \& White, J. W. (2000). Women's vulnerability to sexual assault from adolescence to young adulthood. Journal of Adolescent Health, 27(6), 419-424.

Hägerstrand, T. (1970). What about people in regional science? Papers in regional science association, 24, 7-21.

Kornhauser, R. (1978). Social sources of delinquency. Chicago: University of Chicago Press.

Kunieda, M., \& Gauthier, A. (2007). Gender and urban transport: fashionable and affordable. Sustainable transport: a sourcebook for police makers in developing cities. Eschborn: GTZ.

LeBeau, J. L. (1987). The journey to rape: Geographic distance and the rapist's method of approaching the victim. Journal of Police Science \& Administration, 15(2), 129-136.

Leifman, H., \& Henriksson, C. (2013). Ungdomar som använder nätdroger - vilka är de? In C. f. a.-o. n.-. CAN (Ed.), (Vol. 137, pp. 28). Stockholm: CAN.

Lovett, J., \& Kelly, L. (2009). Different systems, similar outcomes? Tracking attrition in reported rape cases across Europe. London: Child and Woman Abuse Studies Unit.

Loukaitou-Sideris, A. (2014). Fear and safety in transit environments from the women's perspective. Security Journal, 27, 242-256.

Loukaitou-Sideris, A. (2016). A gendered view of mobility and transport: next steps and future directions. Town Planning Review, 87(5).

Maclure, M. (1991). The Case-Crossover Design: A Method for Studying Transient Effects on the Risk of Acute Events. American Journal of Epidemiology, 133(2), 144-153.

Maume, D. J. (1989). Inequality and metropolitan rape rates: A routine activity approach. Justice quarterly, 6(4), 513-527.

McDowall, D., Loftin, C., \& Pate, M. (2012). Seasonal Cycles in Crime, and Their Variability. Journal of quantitative criminology, 28(3), 389-410.

Ministry of Justice (1999). The penal code (pp. 179). Stockholm: Swedish Ministry of Justice. http://mc.manuscriptcentral.com/jiv 
Pyle, G. (1974). The spatial dynamic of crime. Chicago, USA: Department of Geography, University of Chicago.

Rosay, A., \& Langworthy, R. (2003). Descriptive analysis of sexual assualts in Anchorage, Alaska (Vol. JC 0107, pp. 39). Anchorage: Bureau of Justice Statistics.

Sampson, R. J., Raudenbush, S. W., \& Earls, F. (1997). Neighborhoods and Violent Crime: A Multilevel Study of Collective Efficacy. Science, 277(5328), 918-924

Shaw, C. R., \& McKay, H. D. (1942). Juvenile delinquency and urban areas. Chicago: University of Chicago Press.

Stockholm Municipality (2011). Trygg i Stockholm? En stadsövergripande trygghetsmätning. Stockholm: Stockholm Municipality.

Teasdale, B., Daigle, L. E., \& Ballard, E. (2014). Trajectories of Recurring Victimization Among People With Major Mental Disorders. Journal of interpersonal violence, 29(6), 987-1005.

Tewksbury, R., Mustaine, E., \& Covington, M. (2010). Offender Presence, Available Victims, Social Disorganization and Sex Offense Rates. American Journal of Criminal Justice, 35(1-2), 114.

Ullman, S. (2010). Talking about Sexual Assault: Society's Response to Survivors: American Psychological Association.

UN Women. (2014). Safe cities global initiatives. UN, 2. www.unwomen.org

Ward, T., \& Siegert, R. J. (2002). Toward a comprehensive theory of child sexual abuse: A theory knitting perspective. Psychology, Crime \& Law, 8(4), 319-351.

Warr, M. (1985). Fear of Rape among Urban Women. Social Problems, 32(3), 238-250.

Wiebe, D. J., Richmond, T. S., Poster, J., Guo, W., Allison, P. D., \& Branas, C. C. (2014). Adolescents' fears of violence in transit environments during daily activities. Security Journal, 27(2), 226-241.

Wikström, P.-O., Ceccato, V., Hardie, B., \& Treiber, K. (2010). Activity Fields and the Dynamics of Crime. Journal of quantitative criminology, 26(1), 55-87.

Wortley, R. (2010). Critiques of situational crime prevention. In B. F. S. Lab (Ed.), Encyclopedia of Victimology and Crime Prevention (pp. 1-9). Thousand Oaks, CA: Sage. http://mc.manuscriptcentral.com/jiv 
Vrotsou, K., Ynnerman, A., Cooper, M. (2014). Are we what we do? Exploring group behaviour through user-defined event-sequence similarity. Information Visualization, 13(3):232-247, 2014.

Vrotsou, K., Ellegård, K., \& Cooper, M. (2009). Exploring time diaries using semi-automated activity pattern extraction. International Journal of Time Use Research, 6(1), 1-25. 


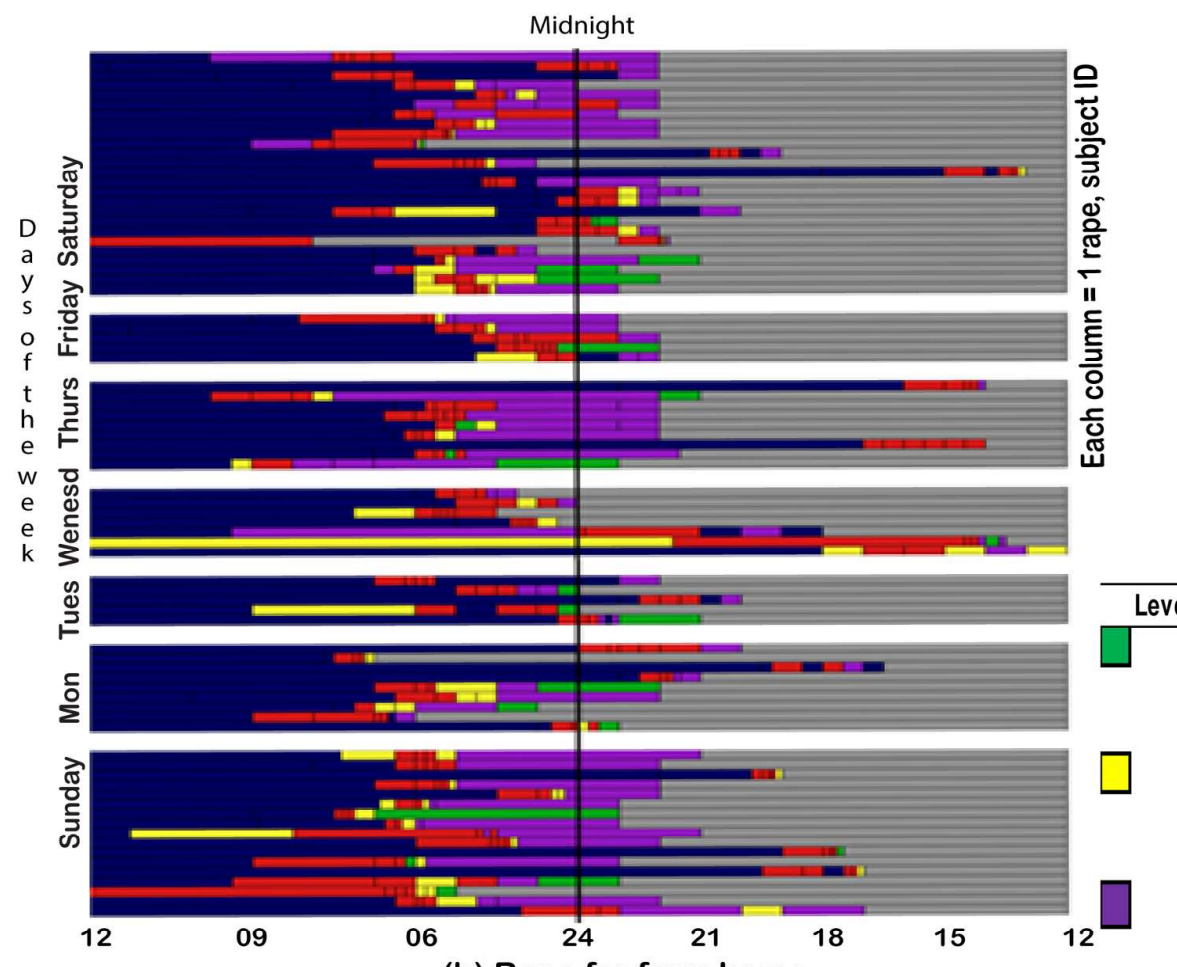

(b) Rape far from home

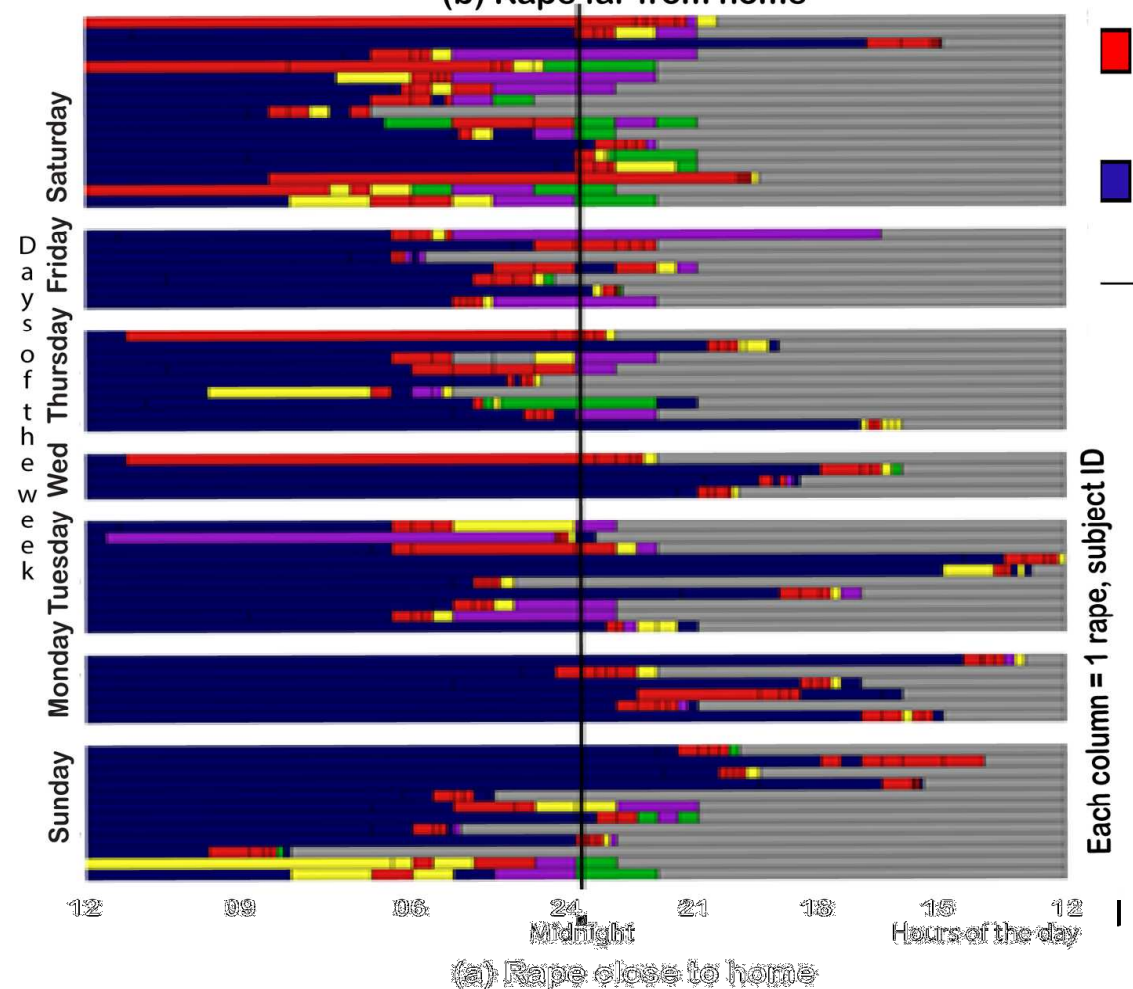

(a)

\begin{tabular}{|c|c|c|}
\hline Level of Detai & Cod & Activity description \\
\hline 3 & 100 & PRIVATE ACTIMTIES \\
\hline 2 & 110 & Personal care \\
\hline 1 & 111 & Example: Eating/drinking \\
\hline 3 & 200 & MOBILITY ACTIMTIES \\
\hline 2 & 210 & Transportation \\
\hline 1 & 211 & Exemple: Walking \\
\hline 3 & 300 & SOCIAL ACTIVTIIES \\
\hline 2 & 310 & Communication \\
\hline 1 & 311 & Example: Talk face-to-face \\
\hline 3 & 400 & RAPE REL. ACTIMTIIES \\
\hline 2 & 410 & Beforelafter offence \\
\hline 1 & 411 & Example: Pushed somewhere \\
\hline 3 & 500 & OTHER ACTIMTIES \\
\hline 2 & 510 & Get help \\
\hline 1 & 511 & Example: Go to police \\
\hline
\end{tabular}

Figure 1 - Each rape and the time before and after it using VISUAL-TimePAcTS. Examples of patterns of activities in two types of rape, (a) close to home (b)far from home. Color represents the activity category of each event, corresponding to the most general activity descriptions. Private activities are displayed in green, transportation activities in yellow, social activities in purple, rape-related activities in red and other activities in blue. 


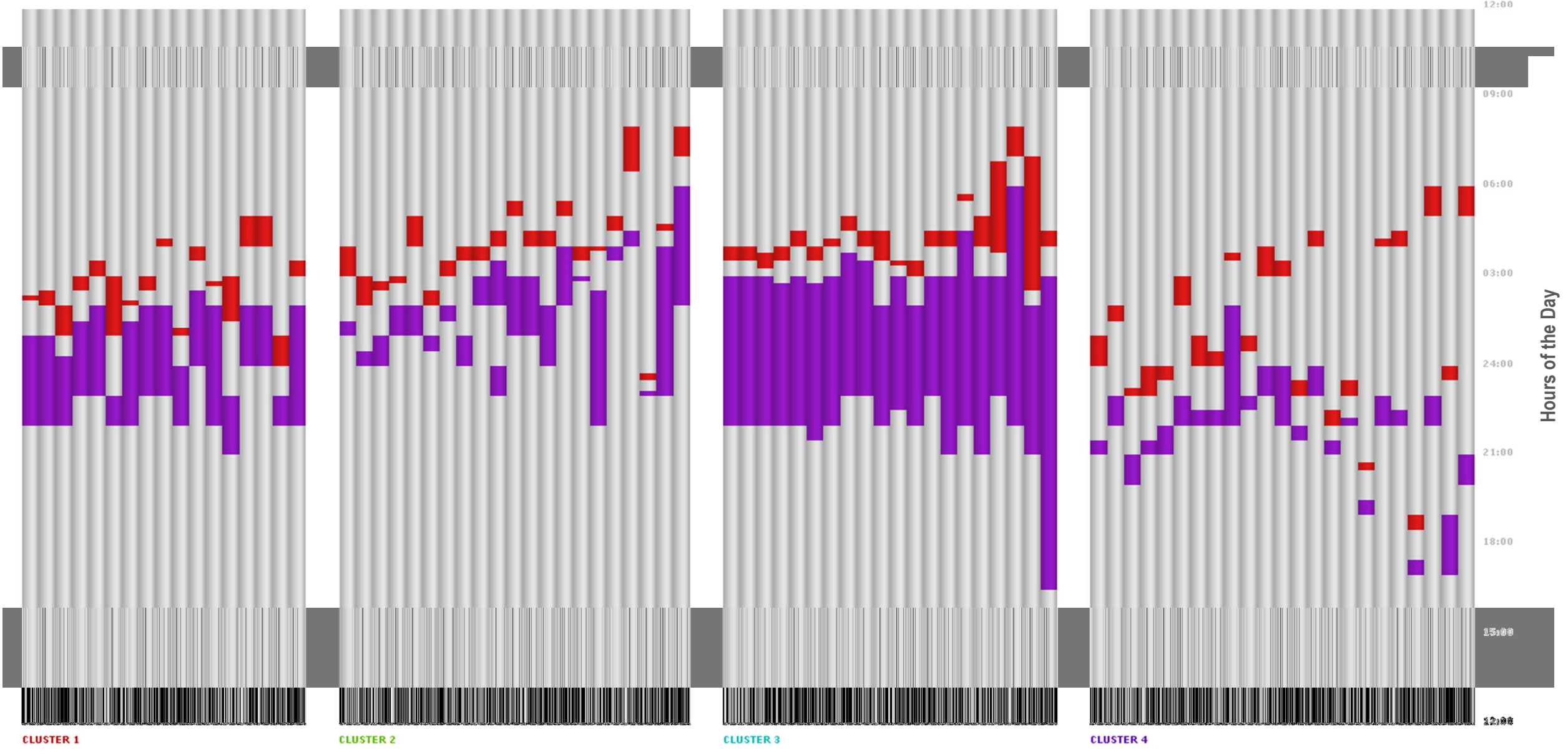

Each column $=1$ rape, Subject ID

Figure 2 - Women's activity clusters with regard to how the sequential pattern drinking (purple) was followed by rape (red). 
Table 1 - The association between each pre-rape station or setting and the risk of rape

\begin{tabular}{|c|c|c|c|c|c|c|}
\hline Cell a & Cell b & Cell C & Cell d & & & \\
\hline Exposed & Exposed & Not exposed & Not exposed & & & \\
\hline during & during & during & during & & & \\
\hline pre-rape & pre-rape & pre-rape & pre-rape & & & \\
\hline stations and & stations and & stations and & stations and & & & \\
\hline exposed & not exposed & exposed & not exposed & & & \\
\hline earlier & earlier & earlier & earlier & & & \\
\hline in the day & in the day & in the day & in the day & OR & $95 \% \mathrm{Cl}$ & P-value \\
\hline
\end{tabular}

Situation or characteristic in Place type

Private setting

Street setting

Forrested setting

Interstitial setting

Other outdoor setting

Private transport

Public transport

Indoor public setting (reference category)

$\mathrm{OR}$ : odds ratio. $\mathrm{Cl}$ : confidence interval.

* O was replaced with 1 to enble calculation of OR.

Table 2 - Associations between companions and risk taking behavior and the risk of rape

\begin{tabular}{|c|c|c|c|c|c|c|c|}
\hline & Cell a & Cell b & Cell c & Cell d & & & \\
\hline & Exposed & Exposed & Not exposed & Not exposed & & & \\
\hline & during & during & during & during & & & \\
\hline & pre-rape & pre-rape & pre-rape & pre-rape & & & \\
\hline & stations and & stations and & stations and & stations and & & & \\
\hline & exposed & not exposed & exposed & not exposed & & & \\
\hline & earlier & earlier & earlier & earlier & & & \\
\hline Situation or characteristic & in the day & in the day & in the day & in the day & OR & $95 \% \mathrm{Cl}$ & P-value \\
\hline
\end{tabular}

\begin{tabular}{|c|c|}
\hline \multicolumn{2}{|c|}{ ANALYSIS ON ALL WOMEN ( $n=144)$} \\
\hline Companions & \\
\hline With offender(s) & 48 \\
\hline With close individual(s) & 12 \\
\hline Alone & 11 \\
\hline \multicolumn{2}{|l|}{ Risk taking } \\
\hline In a risky social context & 104 \\
\hline Engaged in a risky activity & 112 \\
\hline In a risky place & 100 \\
\hline
\end{tabular}

\begin{tabular}{|r|r|}
\hline 84 & 1 \\
\hline $0 *$ & 78 \\
\hline 14 & 74 \\
\hline & \\
\hline 31 & 3 \\
\hline 24 & 7 \\
\hline 13 & 17 \\
\hline
\end{tabular}

the day
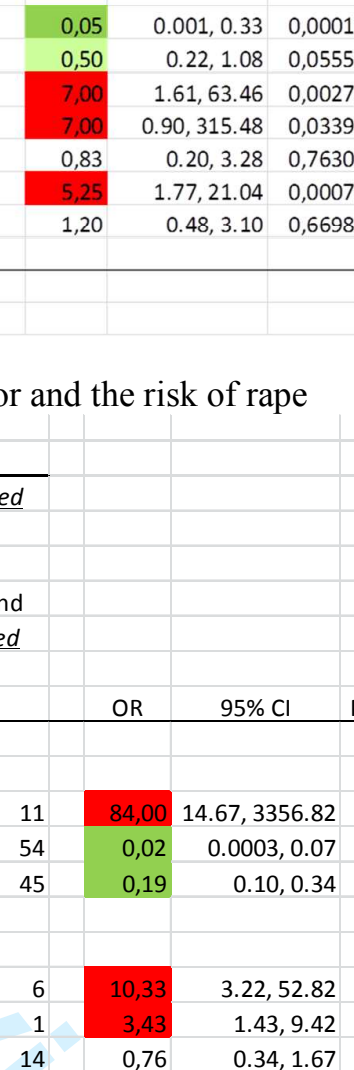

In a risky place

100

84,001

0,19

$<0.001$ $0.0003,0.07<0.001$ $0.10,0.34<0.001$

ANALYSIS ONLY ON WOMEN WHO NEVER DRANK ALCOHOL $(n=51)$

Companions

With offender(s)

With close individual(s)

Alone

24
10
7

\begin{tabular}{l|}
\hline 60 \\
$0 *$ \\
13
\end{tabular}

\section{)}

Risk taking

In a risky social context

Engaged in a risky activity

In a risky place

13

\section{0*}

$0 *$
65

65
39

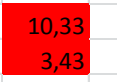
$1.43,9.42 \quad 0,002$

\begin{tabular}{ll}
$0.34,1.67 \quad 0,465$ \\
\hline
\end{tabular}
$3.22,52.82<0.001$

\begin{tabular}{|r|r|}
\hline 61 & 25 \\
\hline 31 & 17 \\
\hline 34 & 5 \\
\hline
\end{tabular}

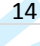

0,76

\section{ANALYSIS ONLY ON WOMEN WHO DID DRINK ALCOHOL $(n=93)$}

Companions

With offender(s)

With close individual(s)

Alone

\section{Risk taking}

In a risky social context

Engaged in a risky activity

In a risky place

OR: odds ratio. $\mathrm{Cl}$ : confidence interval.

* 0 was replaced with 1 to enble calculation of OR. 